\title{
Statistical Performances of Population Migration in the Republic of Macedonia at the Beginning of the $21^{\text {st }}$ Century
}

DOI: $10.11567 /$ met.30.1.2 UDK: 314.7(497.7)"2000/2011" Izvorni znanstveni rad Primljeno: 19.11.2013. Prihvaćeno: 3.6.2014.

\author{
Kosta Sotiroski
}

University "St. Clement of Ohrid" - Bitola, Faculty of Economics - Prilep, Prilep kostasotiroski@ymail.com

Ilija Hristoski

University "St. Clement of Ohrid" - Bitola, Faculty of Economics - Prilep, Prilep ilija.hristoski@uklo.edu.mk

\begin{abstract}
SUMMARY
The Republic of Macedonia has always been considered a highly intensive migration area, characterized by both exhaustive inner movements of its citizens, as well as continuous emigration processes towards other countries. This paper is focused on exploring and analyzing the volume, dynamics, trends, demographic characteristics, and the variability of migration flow modalities in the country during the first decade of the $21^{\text {st }}$ century, as well as their conjunction and effects on the socio-economic factors. Having in mind the diversities of the migration flows within the country, the expected outcomes are projected towards discovering relevant information about their changes, their trends, and the interaction between the basic indicators being acquired by appliance of relevant statistical migration-related metrics and those portraying the statistical regions' development in the specified period of time.
\end{abstract}

KEY WORDS: migration balance, immigration, emigration, indicators of regional development, statistical inference, Republic of Macedonia

\section{INTRODUCTION}

The mechanical (physical) movement of residents, also known as "population migration" or "human migration", is a global, yet continuous and variable process over time. Human migrations appear in different modalities, such as permanent or temporary, internal (local, intra-regional, regional) or external (across borders), economically or politically induced, forced or voluntary, legal or illegal etc. The reasons that initiate human migrations 
have different modalities, too, and both their volume and impact intensity varies in different time periods. As a result, the structure of the labour market changes and novel tendencies in regional development are initiated, as well.

The Republic of Macedonia has always been considered a highly intensive migration area, characterized by both exhaustive inner movements of its citizens, as well as continuous emigration processes towards other countries.

Historically, the internal migration flows within the Republic of Macedonia have exhibited different intensities in specific time periods. In general, they still occur from villages to towns, especially towards the capital city of Skopje, both from rural and urban places. The most intensive wave of rural-to-urban migrations happened during the 1960's and 1970's, a time period known as "the industrialization period". During this period, it has been estimated that more than 175,000 inhabitants have left rural places and have moved into towns and cities, in order to resolve their existential problems. Such an immense migration flow has implied a "rural exodus" to cities, especially the city of Skopje, followed by significant consequences in the process of demographic aging both on a regional and geographic scale (Стратегија за демографски развој на Република Македонија: 2008 - 2015, 2008: 12-13). Combined with emigration flows towards third countries, the internal migrations have led to depopulation and reduction of the migration potential in rural areas, which has involved a relative depressing of internal migration levels during the last two decades. It should also be noted that internal migrations at the beginning of the last decade have been triggered, to a certain extent, by the war conflict between Macedonian security forces and the Albanian separatists in 2001, when about 76,000 inhabitants, mainly from the Skopje, Kumanovo, and Tetovo regions, were forced to leave their homes looking for safety and protection throughout the country (Bornarova and Janeska, 2012: 2).

The phenomenon of migrations from the Republic of Macedonia has a long tradition, lasting for more than 100 years. The prevailing destinations have always been the West-European countries, as well as overseas countries, including the USA, Canada, and Australia. For instance, more than 170,000 Macedonian citizens migrated to only three West-European countries from 1998 to 2011, these including Germany, Italy, and Switzerland, according to EUROSTAT (Митковска, 2014). The emigration flows have characterized not only the $20^{\text {th }}$ century, but they have also continued in the first decade of the $21^{\text {st }}$ century. In fact, the contemporary emigration flows 
from the Republic of Macedonia to third countries have shown a trend of constant increase during the last four decades, followed by crucial changes in the structural characteristics of the emigrants, their directions of movements, the reasons for migration, as well as the period of stay abroad (Resolution on Migration policy of Republic of Macedonia: 2009-2014, 2008: 3). Those changes correspond to the phases of social and economic development in the country, also reflecting the changes in migration policies being introduced by the countries where Macedonian emigrants settle. In fact, the biggest emigrant wave of about 200,000 inhabitants, originating from the Republic of Macedonia towards third countries, has begun after the country gained its independence in 1990. It was induced by the severe economic crisis that struck the country from the beginning of transition, since the poverty rate escalated enormously, and the unemployment rate levelled out above $30 \%$ in continuity (Bornarova and Janeska, 2012: 2).

However, despite the dimensions of migration flows from the Republic of Macedonia, the statistical evidence about such dimensions is relatively poor. Moreover, the exact number of Macedonian citizens staying and living out of the borders of the country cannot be determined precisely. According to the existing analyses that are primarily based on the officially published population census data, the decrease in Macedonian population due to international migrations is considerably smaller than the one caused by internal migration flows. For instance, about 50,000 inhabitants have left the Republic of Macedonia from 1989 to 1994, whilst 173,611 Macedonian citizens lived outside the borders of the country according to the 1994 population census statistics. However, based on the evidence provided by foreign countries to which Macedonian emigrants migrate, it has been estimated that the emigration rate is between 10,000 and 15,000 persons per annum (Стратегија за демографски развој на Република Македонија: 2008 - 2015, 2008: 12-13). In 2012, EUROSTAT has announced that the number of emigrant Macedonian citizens in foreign countries has reached 550,000, which represent $26 \%$ of the total number of inhabitants in the Republic of Macedonia (Bornarova and Janeska, 2012: 2; Митковска, 2014). On the other hand, the US Statistical Bureau claims that the number of Macedonian citizens in overseas and other countries is over 470,000, which is more than 100,000 less than the number given by EUROSTAT (Митковска, 2014).

Despite the fact that official institutions in the Republic of Macedonia conceal the numbers regarding emigrants from the country, whilst the estimation of 230,000 regularly emigrated persons from 1998 to 2011, made by EUROSTAT for 2012, is still the actual and operational one, it is quite 
clear that the number reaches dramatic heights, since it does not include those who stay and work abroad illegally. However, it is estimated that the number of the latter is even higher than the number of regular emigrants. Yet, more disturbing is the fact that not just single persons of late, but whole Macedonian families have been emigrating abroad more frequently than ever before. As a result, the number of newborns is steadily increasing from 3,510 Macedonian children born abroad in 2009, to 4,221 in 2012, according to the evidence provided by the State Statistical Office of the Republic of Macedonia (Митковска, 2014).

In general, the contemporary migrant flows from/into and within the Republic of Macedonia have been induced by several dominant factors, including the following ones: the unfavourable overall economic situation, especially the unfavourable situation on the labour market, the high participation of young population in the total number of unemployed persons, and the problem of unemployed, yet highly educated people, which has escalated both in volume and structure during recent years. Furthermore, highly negative demographic trends are also evident, as well as significant differences in regional economic and social development, which altogether have led to severe social differentiation within the society, inequalities and differences, regional demographic disparities, unequal and unsustainable territorial distribution of the population, poor quality of life, as well as an absence of social cohesion (Стратегија за демографски развој на Република Македонија: 2008 - 2015, 2008: 35). The Republic of Macedonia is still an insufficiently developed country, characterized by low GDP rates and, therefore, it cannot provide the minimum number of working positions to satisfy the high volume of the unemployed workforce (Митковска, 2014).

The migrations' effect on the demographic image is twofold. First of all, it has a direct impact on the statistics, the territorial distribution, and the population structure. On the other, it determines the birth rate and the mortality rate due to the consequences of the changes in the gender and the age structure of the population. The places and regions hit by emigration flows suffer a lack of workers, and there are unexploited physical resources, as well. Quite the opposite, the places and regions to which immigrants migrate suffer a surplus of workers, leading towards unemployment, poverty, increased population density, as well as the decreased well-being of individuals and societies, otherwise known as the "quality of life".

In that context, it is inevitable to encompass and analyze statistically and on a regular basis the relevant data about population migrations in a specified time period and in previously defined statistical regions, in order to 
draw corresponding statistical conclusions, and make subsequent forecasts, projections, or simulations (HTEC, 2007).

The paper is structured as follows: after the introduction to the substance, the subject, goal, and methodology underlying the research have been elaborated, followed by an overview of the related recent research done on this topic. Next, a statistical analysis of the population migration from/into the Republic of Macedonia by statistical regions for 2000 and 2011 has been presented, along with the corresponding statistical indicators. Based on the later ones, statistical inferences about population migration in the Republic of Macedonia, given by statistical regions and for the observed time period, have been drawn through assessment of several statistical hypotheses. The concluding remarks, being extracted from the statistical analysis, are given at the end, pointing out recommendations on facilitating further exploration of migrations within the country.

\section{SUBJECT,GOAL,AND METHODOLOGY}

This research is focused on exploring and analyzing the volume, dynamics, trends, and demographic characteristics, as well as the variability of migration flow modalities in the Republic of Macedonia at the beginning of the $21^{\text {st }}$ century, as well as their conjunction and effects on the socio-economic factors. Having in mind the diversities of the migration flows within the country, the expected outcomes are projected towards discovering relevant information about their changes, their trends, and the interaction between the basic indicators being acquired by appliance of relevant statistical migration-related metrics and those portraying the statistical regions' development in the defined period of time. In order to accomplish successfully the defined goal, the following plan of statistical research has been implemented, along with corresponding research methodology:

- Identification of relevant sources of statistical data, both primary and secondary, about the migration movements in the Republic of Macedonia within the defined time frame, followed by their acquisition, completion, preparation, grouping, and processing, using the methods of descriptive statistics;

- Creation of an interaction between the migration-related indicators and the indicators of the statistical regions' development, by employing data processing with the methods of the regression and correlation analysis;

- Definition of statistical hypotheses and carrying out a statistical inference for different modalities of migration movements in various time instances within the observed period of time. This has been accomplished by using the 
parametric ANOVA test, and the contingency test $\left(\chi^{2}\right)$, as well (Сотироски, 2004: 301-323, 275-279; Kranzler, 2007);

- Realization of the above mentioned statistical analyses through relevant software support, including IBM ${ }^{\circledR}$ SPSS $^{\circledR}$ Statistics (Allen and Bennett, 2012; Kirkpatrick and Feeney, 2012).

This concept inevitably introduces the necessity of creating statistical indicators, i.e. elements of statistical metrics for migration movements, including: migration balance ${ }^{1}$, migration balance rate $^{2}$, emigration rate (rate of outflow) ${ }^{3}$ and immigration rate (rate of inflow) ${ }^{4}$. These metrics, along with the indicators of the regional development that refer to various statistical regions in the Republic of Macedonia, should be continuously assessed, computed, and compared over time, since they are supposed to be fundamental constitutional elements of the human migration database for the country, as well as a subject of corresponding statistical analysis and inference.

\section{RELATED RESEARCH}

In general, considerably little research has been conducted so far on migration in the Republic of Macedonia, taking into account the dimensions of this global phenomenon. The main reason for this is the absence of relevant data that is systematically and continuously collected on a regular basis, being unified both by its format and nature, and, at the same time, being trustworthy, as well. Despite the existence of several domestic bodies that deal with migration data (e.g. the Agency of Emigration of the Republic of Macedonia, the State Statistical Office of the Republic of Macedonia, the Ministry of Foreign Affairs of the Republic of Macedonia, the Ministry of Labour and Social Policy of the Republic of Macedonia), there are huge discrepancies in the dynamics, quality and scope of the raw data being collected, processed, or made available by these sources. On the other hand, such data is still considered quite sensitive due to political reasons, as well as in the whole region encompassing the Balkan countries, and therefore it is not

1 Migration balance equals the difference between the number of immigrants and the number of emigrants in the specified time period.

2 Migration balance rate [\%o] is a ratio between the migration balance and the average number of residents in a specified time period, multiplied by a factor of 1000 .

3 Emigration rate (rate of outflow) [\%o] is a ratio between the number of emigrants and the average number of residents in a specified time period, multiplied by a factor of 1000 .

4 Immigration rate (rate of inflow) [\%o] is a ratio between the number of immigrants and the average number of residents in a specified time period, multiplied by a factor of 1000 . 
always accessible, at least not to an extent and/or in a form suitable for exploratory usage. This impedes, or, in the best case, complicates the scientific analyses, assessments and predictions. In most cases, more systematic and up-to-date information has been obtained by foreign organizations, rather than domestic ones.

However, the recent, ever-increasing number of published scientific papers and organized meetings focused on this complex and important issue point out the necessity of its thorough and continuous tracking and evaluation, bearing in mind the multiple aspects: demographic, social, economic, political, ethnical, national etc. In that sense, it is worth mentioning some of the recent and most important research endeavours. One of the first scientific attempts dealing with the migration characteristics of the population in the Republic of Macedonia, based on the 1981 and 1994 census data, has been presented by Bubevski (2001). He has focused mainly on the migration balance between the autochthonous and immigrated population. Kljusev (2007) has elaborated the volume and structure of the immigrated population within the Republic of Macedonia from 1994 to 2003 . He has also analyzed the number of Macedonian citizens who have resided in certain European countries from 1996 to 2004, as well as the number of Macedonian emigrants in overseas countries. Jakimovski (2007) has focused on the changes in the volume and spatial distribution of the population in the Skopje region from 1994 to 2002, based on 2002 population census data. ${ }^{5}$ Janeska and Ivanoska (2007) have elaborated the structure of the autochthonous and immigrated population in the Republic of Macedonia from 1994 to 2002, as well as the internal migrations from 1994 to 2004. In addition, they have analyzed the internal and external migrations by regions from 1994 to 2004, and the demographic characteristics of the migrants, as well. Talevski (2007) has analyzed the migration balance of the total, urban, and rural population in the Republic of Macedonia according to the population censuses held from 1948 to 2002. Macedonian post-socialist migrations have been put into focus by Avirović (2012). However, the recent explorations of strictly demographic migrations on a national level have been carried out by Joveski (2012), and Trajkova and Andonov (2012). In addition, the demographic changes in the Republic of Macedonia, caused by professional and social migrations, known as "social mobility", have been elaborated by the recent work of Cacanoska and Slaninka-Dineva (2012).

Most of the recent research has also been focused on treating labourrelated migrations and the effects of the migrations on the labour markets,

The 2002 population census has been the last one organized in the Republic of Macedonia. 
since it is closely related to the current problem of the high unemployment rate in the Republic of Macedonia. For instance, significant contributions in this area have recently been given by Popovski and Tosheva (2012), Bejzaroski (2012), Nikolovski, Žibak and Nikolovska (2012), as well as Janeska (2013). The global dimensions of international economic migrations with special emphasis on the immigration situation in the Republic of Macedonia have been elaborated by Chudoska-Blazevska, Malici and Zununi (2012).

Besides these, some domestic researchers have focused on investigating regional/local migrations within the country, including Gjurovski (2012), Abdulai, Durmishi and Kadrius (2012), and Klopchevska (2012). In this context, Vchkov (2012) has explored the phenomenon of daily mobility in the Republic of Macedonia, with special emphasis on its incidence in the Municipality of Veles.

The effort of Ivanovska and Jovcheska (2012), who have investigated the relationship between education, unemployment, and migrations in the Republic of Macedonia, is also worth mentioning, focusing as it does on the phenomenon of "brain drain" and proposing measures for its replacement with the trend of a "brain exchange".

\section{STATISTICAL ANALYSIS OF THE POPULATION MIGRATION}

Migratory movements in the Republic of Macedonia have been expressed through the total number of immigrants and emigrants flowing in/ from the country, along with all of their modalities, observed in statistical regions (Figure 1), for 2000 and 2011. Table 1 has been obtained by sublimating relevant statistical data about immigrants inflowing to the Republic of Macedonia (2000/2011). 
Figure 1. Statistical regions within the Republic of Macedonia

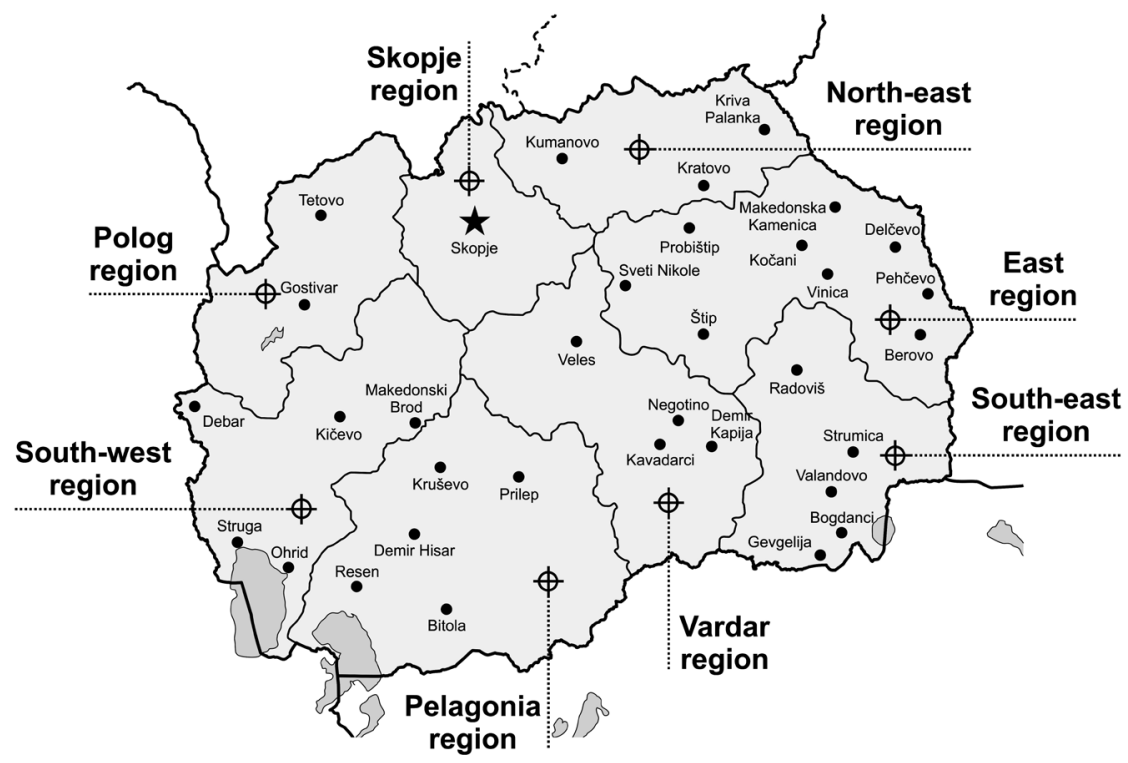

Table 1. Total number of immigrants in the Republic of Macedonia, by statistical regions (2000/2011)

\begin{tabular}{lcc}
\hline & \multicolumn{2}{c}{$\begin{array}{l}\text { Total number of } \\
\text { immigrants in the } \\
\text { Republic of Macedonia }\end{array}$} \\
\cline { 2 - 3 } & $\mathbf{2 0 0 0}$ & $\mathbf{2 0 1 1}$ \\
\hline Pelagonia region & 1,118 & 1,100 \\
Vardar region & 702 & 616 \\
North-east region & 988 & 597 \\
South-west region & 1,127 & 1,088 \\
Skopje region & 6,022 & 2,014 \\
South-east region & 969 & 754 \\
Polog region & 1,076 & 908 \\
East region & 1,056 & 884 \\
\hline TOTAL & 13,058 & 7,961 \\
\hline
\end{tabular}


Table 2. Total number of immigrants within the Republic of Macedonia, by statistical regions (2000/2011)

\begin{tabular}{lrr}
\hline & \multicolumn{2}{c}{$\begin{array}{c}\text { Total number of } \\
\text { immigrants within the } \\
\text { Republic of Macedonia }\end{array}$} \\
\cline { 2 - 3 } & $\mathbf{2 0 0 0}$ & $\mathbf{2 0 1 1}$ \\
\hline Pelagonia region & 1,058 & 709 \\
Vardar region & 685 & 445 \\
North-east region & 972 & 386 \\
South-west region & 1,034 & 710 \\
Skopje region & 5,903 & 1,952 \\
South-east region & 963 & 617 \\
Polog region & 764 & 556 \\
East region & 1,040 & 673 \\
\hline TOTAL & 12,419 & 6,048 \\
\hline
\end{tabular}

Table 1 shows that the total number of immigrants in the Republic of Macedonia in 2011 has been 1.64 times (39\%) less than the corresponding one in 2000 (Statistical Yearbook of the Republic of Macedonia, 2001: 90-95, 102-104; 2012: 102-105). The decreasing trend has been the most distinctive in the Skopje region (the number of immigrants in 2011 has decreased by almost 3 times or $66.55 \%$, in comparison to 2000) whilst the smallest decrease has been observed in the Pelagonia region (the number of immigrants in 2011 has decreased about $1.6 \%$ in comparison to 2000). One should also mention that the total number of immigrants within the Republic of Macedonia in 2011 has decreased by $51.3 \%$ compared to 2000, which is more than 2 times (Statistical Yearbook of the Republic of Macedonia, 2001: 84-89). Such a decrease is evident for all statistical regions within the country. The analysis of the sublimated data has shown that the number of immigrants in the Republic of Macedonia from abroad has decreased by $45.38 \%$ in 2011, compared to 2000. The decrease is most evident in the Polog region $(80.12 \%$ or almost 5 times). Considerable decreases are also obvious in the Skopje region, the South-west region, the East region, as well as in the Vardar region. Despite this decreasing trend, the Pelagonia region is facing an increase in 
the number of immigrants from foreign countries of $72.72 \%$ or 3.67 times in 2011, compared to 2000.

In the Republic of Macedonia, the number of immigrated persons within the country in 2011 has decreased by more than 2 times, compared to 2000 . The decreasing trend is obvious in all statistical regions. From 2000 to 2011 the most prevalent relative decrease of the immigrants' flows within the country is noticeable in the Skopje region $(66.93 \%)$, and in the North-east region $(60.29 \%)$, as well. The smallest decrease of the immigrants' flows within the country is evident in the Pelagonia and Polog regions (Table 2).

The conclusions drawn from the statistical analysis of the data presented in Table 3 have indicated that the total number of emigrants in the Republic of Macedonia in 2011 has decreased by $29.73 \%$ in comparison to 2000. This is most evident in the Skopje region, where the decrease is $73.38 \%$ or 3.75 times. Such a decreasing trend is also evident in the East region, South-east region, North-east region, the Vardar region, as well as in the Pelagonia region. However, this is not the case with the South-west and the Polog region, where an increase in the number of emigrants by $82.31 \%$ and $18.49 \%$ has been observed, respectively.

Table 3. Total number of emigrants in the Republic of Macedonia, by statistical regions (2000/2011)

\begin{tabular}{lrr}
\hline & \multicolumn{2}{c}{$\begin{array}{l}\text { Total number of } \\
\text { emigrants in the } \\
\text { Republic of Macedonia }\end{array}$} \\
\cline { 2 - 3 } & $\mathbf{2 0 0 0}$ & $\mathbf{2 0 1 1}$ \\
\hline Pelagonia region & 1,107 & 1,044 \\
Vardar region & 774 & 689 \\
North-east region & 1,166 & 737 \\
South-west region & 1,080 & 1,969 \\
Skopje region & 5,320 & 1,416 \\
South-east region & 1,071 & 761 \\
Polog region & 833 & 987 \\
East region & 1,233 & 1,152 \\
\hline TOTAL & 12,584 & 8,755 \\
\hline
\end{tabular}


Table 4. Total number of emigrants from the Republic of Macedonia in foreign countries, by statistical regions (2000/2011)

\begin{tabular}{|c|c|c|}
\hline \multirow[t]{2}{*}{ Statistical regions } & \multicolumn{2}{|c|}{$\begin{array}{l}\text { Total number of } \\
\text { emigrants from the } \\
\text { Republic of Macedonia } \\
\text { in other countries }\end{array}$} \\
\hline & 2000 & 2011 \\
\hline Pelagonia region & 12 & 0 \\
\hline Vardar region & 7 & 0 \\
\hline North-east region & 30 & 23 \\
\hline South-west region & 13 & 921 \\
\hline Skopje region & 56 & 21 \\
\hline South-east region & 22 & 7 \\
\hline Polog region & 7 & 83 \\
\hline East region & 18 & 88 \\
\hline TOTAL & 165 & 1,143 \\
\hline
\end{tabular}

Table 4 shows that the total number of emigrants from the Republic of Macedonia in foreign countries in 2011 has increased 7 times, relatively to 2000 (Statistical Yearbook of the Republic of Macedonia, 2001: 96-101, 105-107; 2012: 106-109). The increase is most obvious in the East and Southwest regions, as well as in the Polog region. Notwithstanding, the number of citizens from the Republic of Macedonia who have emigrated abroad in 2011 has decreased by $62.5 \%$ in the Skopje region, as compared to 2000 .

It should be also pointed out that in 2011 all statistical regions were facing a considerable decrease in the number of emigrated persons, bearing in mind the investigated modalities in the age structure, in relation to 2000.

\section{STATISTICAL INDICATORS OF THE POPULATION MIGRATION}

Based on the data available about the population size (number of inhabitants), the number of emigrants, as well as the number of immigrants in the Republic of Macedonia, which are given by statistical regions and for the time period being observed (2000 - 2011), we have computed the following 
statistical indicators: the migration balance, the rate of immigrants, and the rate of emigrants (Table 5, Figure 2), using the proposed metrics.

In the observed time period, the number of inhabitants has decreased only in the East region, by $11.73 \%$. Also, an insignificant decrease in the number of inhabitants is evident in the South-west region. All other regions in the country faced an increased number of inhabitants from 2002 to 2011. The most significant increase in the number of inhabitants $(15.5 \%)$ is evident in the Vardar region. In the observed time period, the population size in the Republic of Macedonia has grown by $1.78 \%$ in total.

Table 5. Migration balance rates, by statistical regions (2000/2011)

\begin{tabular}{lcclc}
\hline Statistical regions & $\begin{array}{l}\text { Number of } \\
\text { inhabitants } \\
(\mathbf{2 0 0 2 )}\end{array}$ & $\begin{array}{l}\text { Number of } \\
\text { inhabitants** } \\
\mathbf{( 2 0 1 1 )}\end{array}$ & $\begin{array}{l}\text { Migration } \\
\text { balance rate } \\
\text { [\%o] } \\
\mathbf{( 2 0 0 0 )}\end{array}$ & $\begin{array}{l}\text { Migration } \\
\text { balance rate } \\
\text { [\%o] } \\
\mathbf{( 2 0 1 1 )}\end{array}$ \\
\hline Pelagonia region & 238,136 & 233,628 & 0.0461 & 0.2396 \\
Vardar region & 133,180 & 153,822 & -0.5406 & -0.4745 \\
North-east region & 172,787 & 175,266 & -1.0301 & -0.7987 \\
South-west region & 221,546 & 221,517 & 0.2121 & -3.9771 \\
Skopje region & 578,144 & 605,899 & 1.2142 & 0.9869 \\
South-east region & 171,416 & 173,056 & -0.5950 & 0.0404 \\
Polog region & 304,125 & 315,964 & 0.7990 & -0.2500 \\
East region & 203,213 & 179,387 & -0.8710 & -1.4939 \\
\hline Rep. of Macedonia & $2,022,547$ & $2,058,539$ & 0.2339 & -0.3857 \\
\hline
\end{tabular}

* There is no data for the number of inhabitants by statistical regions for the year 2000 in the Statistical Yearbook of the Republic of Macedonia: 2000 (2001); therefore, we approximate these by the 2002 figures, given in the Номенклатура на територијални единици за статистика на Република Македонија (2005), by assuming that there is no significant difference.

** The numeric values of data have been estimated according to Pегионите во Република Македонија, 2012 / Regions of the Republic of Macedonia, 2012 (2012): 93-107, since the 2011 population census has been cancelled due to uncertain reasons, which have not been clarified to date. 
Figure 2. Migration balance rates in the Republic of Macedonia, by statistical regions (2000/2011)

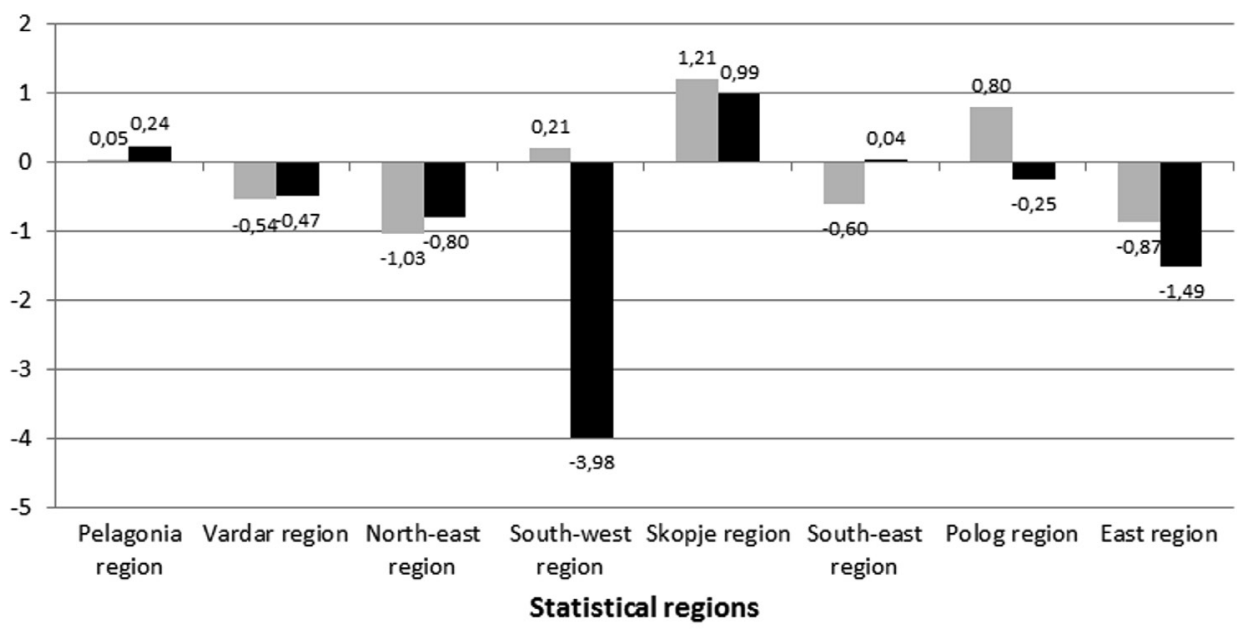

Migration balance rate [\%o] (2000) M Migration balance rate [\%०] (2011)

In 2000, the number of immigrants in the Republic of Macedonia was $3.63 \%$ higher than the number of the emigrants, thus yielding a positive migration balance rate.

According to Table 5, the number of emigrants in the Vardar region in 2000, as well as in the North-east, South-east and the East region, is higher than the number of immigrants, thus putting them into the class of emigration areas. On the other hand, the Pelagonia region has a balanced migration rate, whilst the South-west region, the Skopje region, and the Polog region belong to immigration areas (the number of immigrants is higher than the number of emigrants), since their corresponding migration balance rates are, respectively, $0.98 \%, 11.66 \%$ and $22.58 \%$.

In 2011, the relative increase in the total number of emigrants in the Republic of Macedonia against the total number of immigrants was $9.07 \%$, thus yielding a negative migration balance rate (Table 5).

In the Vardar region, the North-east region, the South-west region $(44.74 \%)$, the Polog region, as well as in the East region $(23.26 \%)$, the number of emigrants is higher than the number of immigrants, whilst in the Skopje region (29.69\%), the South-east, and in the Pelagonia region, the number of immigrants is higher than the number of emigrants. The South-west region and the East region are significant emigration areas. The Skopje region 
and the Pelagonia region remain immigration areas, whilst the South-east region and the Polog region transit from immigration to emigration areas and vice-versa.

The migration balance rate value in the Republic of Macedonia in the observed time period has changed from a positive one $(+0,2339 \%)$ to a negative one $(-0,3857 \%$ o, which means that more people emigrate than immigrate.

The Pelagonia region and the Skopje region have continuously retained positive values of the migration balance rates, despite the evident decrease of the rate's value in the Skopje region and its increase in the Pelagonia region.

On the other hand, the Vardar region, the North-east region, the Southeast region and the East region have continuously retained negative values of the migration balance rates. An insignificant increase in the migration balance rate's negative value has been observed in the East region, whilst the increase in the other regions' migration balance rates is rather significant.

A shift from a positive to a statistically significant negative value of the migration balance rate has been detected for the South-west and the Polog regions.

In 2000, the highest positive value of the migration balance rate has been detected in the Skopje region, whilst the highest negative value has been observed in the North-east region. In 2011, the highest positive value of the migration balance rate has been detected again in the Skopje region, whilst the highest negative values have been observed in the South-west and the East regions.

In 2000, the immigration rate's value was higher than the emigration one (Figures 3 and 4). The highest values of the immigration rate have been detected in the Skopje region $(10.416 \%$ o), the South-east region $(5.6529 \%$ o), as well as in the North-east region (5.518\%o), whilst its lowest value $(3.5380 \%$ o) is specific for the Polog region.

The highest values of the emigration rate have been detected in the Skopje region $(9.2018 \%$ ) , the North-east region $(6.7481 \%$ ), as well as in the South-east region $(6.2479 \%$ o), whilst its lowest value $(2.7390 \%$ ) is specific, again, for the Polog region.

In 2011, the emigrant rate within the Republic of Macedonia had higher value $(4.253 \%$ ) than the immigrant rate $(3.8673 \%$ ), which is not the case as with 2000.

The highest immigrant rate values in 2011 can be detected in the East region $(4.9278 \%$ o), the South-west region, as well as in the Pelagonia regi- 
on, whilst the highest emigrant rate values are evident for the South-west $(8.8887 \%$ o), the East and the Vardar regions.

In 2011, there was a significant decline of these two measures' rates for the South-west, the East, and the North-east regions, where the values of the emigration rates are higher than those corresponding to the immigration rates. Only the Pelagonia region, along with the Skopje region, had a higher immigration rate compared to the corresponding emigration rate.

Figure 3. Immigration and emigration rates in the Republic of Macedonia, by statistical regions, in 2000

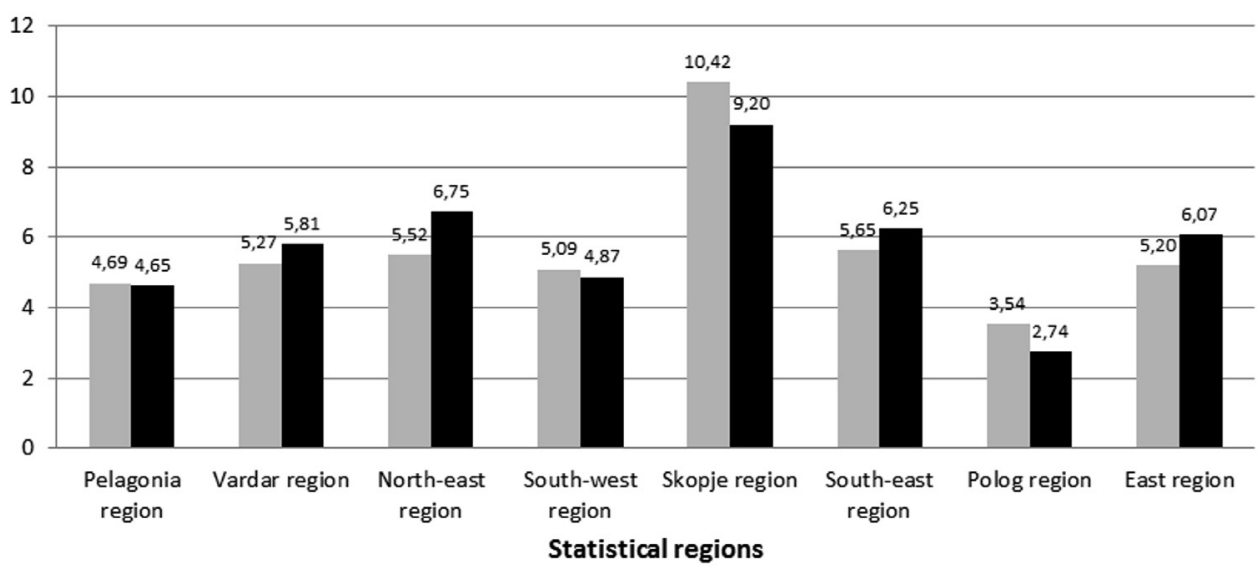

Immigration rate [\%o] (2000) Emigration rate [\%o] (2000)

Figure 4. Immigration and emigration rates in the Republic of Macedonia, by statistical regions, in 2011

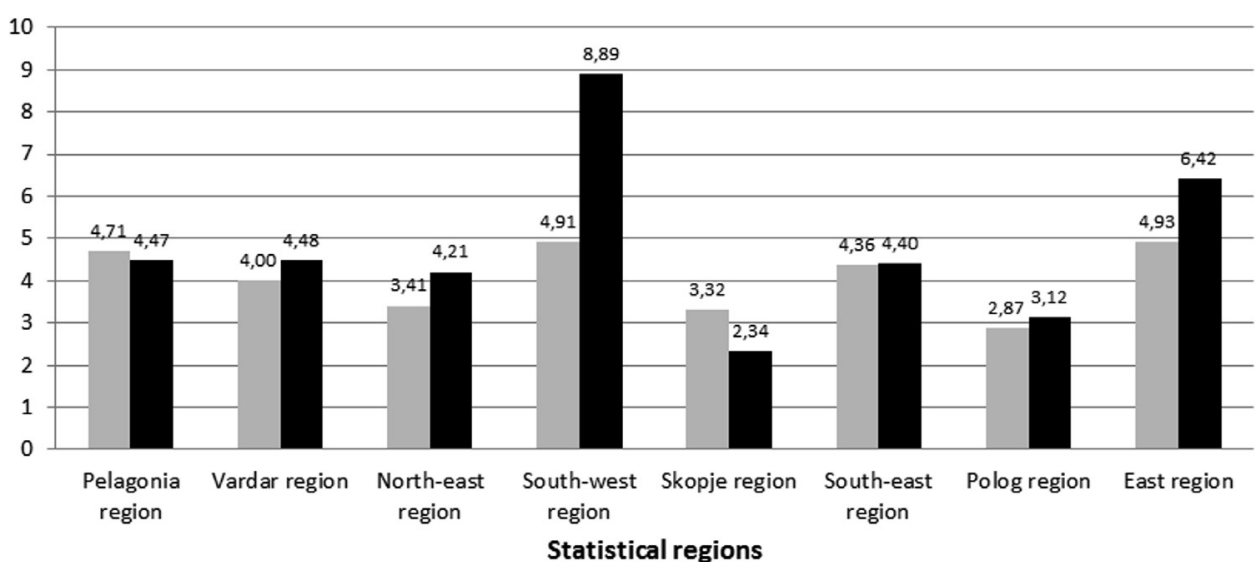

ammigration rate [\%o] (2011) Emigration rate [\%o] (2011) 
If the available migration movements data, encompassing the migrations from/to Republic of Macedonia from 2003 to 2011, is to be statistically analyzed and presented (Table 6, Figure 5), the following conclusions can be drawn: from 2004 to 2010, there is a continuous decrease of the internal migrations' intensity, except in the period from 2010 to 2011, when it shows an upward trend.

From 2003 to 2011, there was a continuous increase in the external migration intensity, which is both more evident and significant from 2003 to 2006. A decrease follows from 2006 to 2008, and afterwards there was a continuous increase in the external migrations number until 2011.

Table 6. Migration movement indicators for the Republic of Macedonia $(2003-2011)$

\begin{tabular}{lccccc}
\hline Year & $\begin{array}{l}\text { Population } \\
\text { size in the } \\
\text { middle of the } \\
\text { year* }\end{array}$ & $\begin{array}{l}\text { Internal } \\
\text { migration }\end{array}$ & $\begin{array}{l}\text { External } \\
\text { migration }\end{array}$ & $\begin{array}{l}\text { Migration } \\
\text { balance }\end{array}$ & $\begin{array}{l}\text { Migration } \\
\text { balance } \\
\text { rate [\%o] }\end{array}$ \\
\hline 2003 & $2,027,000$ & 11,058 & 1,289 & 1,001 & 0.4938 \\
2004 & $2,032,000$ & 11,495 & 2,050 & 712 & 0.3503 \\
2005 & $2,037,000$ & 11,411 & 2,791 & 191 & 0.0937 \\
2006 & $2,040,000$ & 10,740 & 4,381 & 2,165 & 1.0612 \\
2007 & $2,044,000$ & 9,438 & 2,421 & 1,941 & 0.9496 \\
2008 & $2,047,000$ & 8,964 & 2,360 & 858 & 0.4191 \\
2009 & $2,051,000$ & 7,785 & 2,649 & 1,065 & 0.5192 \\
2010 & $2,055,000$ & 7,276 & 3,722 & 1,708 & 0.8311 \\
2011 & $2,059,000$ & 7,612 & 4,501 & 1,921 & 0.9329 \\
\hline
\end{tabular}

* The estimates have been carried out on the basis of the total population, according to the 2002 population census data (Statistical Yearbook of the Republic of Macedonia: 2011, 2012: 72)

Sources: Muгpauиu, 2007 / Migrations, 2007 (2008), Скопје, Државен завод за статистика на Република Македонија / Skopje, State statistical office of the Republic of Macedonia; Muгpaųuи, 2009 / Migrations, 2009 (2010), Скопје, Државен завод за статистика на Република Македонија / Skopje, State statistical office of the Republic of Macedonia; Muгpaųuu, 2010 / Migrations, 2010 (2011), Скопје, Државен завод за статистика на Република Македонија / Skopje, State statistical office of the Republic of Macedonia; Muгpauиu, 2011 / Migrations, 2011 (2012), Скопје, Државен завод за статистика на Република Македонија / Skopje, State statistical office of the Republic of Macedonia. 
Figure 5. Internal and external migrations in the Republic of Macedonia $(2003-2011)$

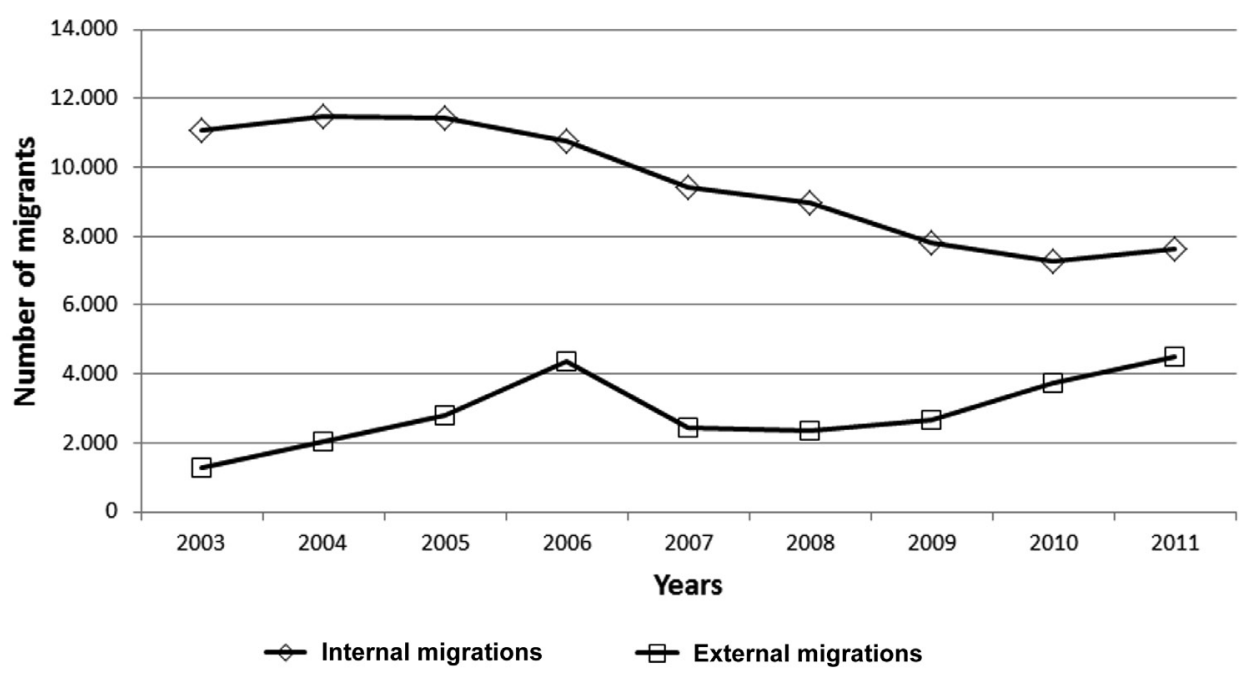

If time series that correspond to internal and external migrations are analyzed, the following statistical indicators, as well as conclusions can be drawn:

- The time series data that cover internal migrations in the Republic of Macedonia from 2003 to 2011 can be approximated most accurately by the cubic trend model (1), since it has the highest value of the coefficient of determination (0.992) among other presented theoretical models; Equation (1) can be utilized for predicting the values of internal migrations in the forthcoming years; The cubic trend approximation can be seen on Figure 6, based on the model summary depicted by Table 6 .

$\hat{y}_{i}=9560.365+2021.877 \cdot x-585.787 \cdot x^{2}+37.383 \cdot x^{3}$

$i=1,2, \ldots, n$ 
Figure 6. Choosing the best fit approximation trend for the internal migrations in the Republic of Macedonia (2003 - 2011)

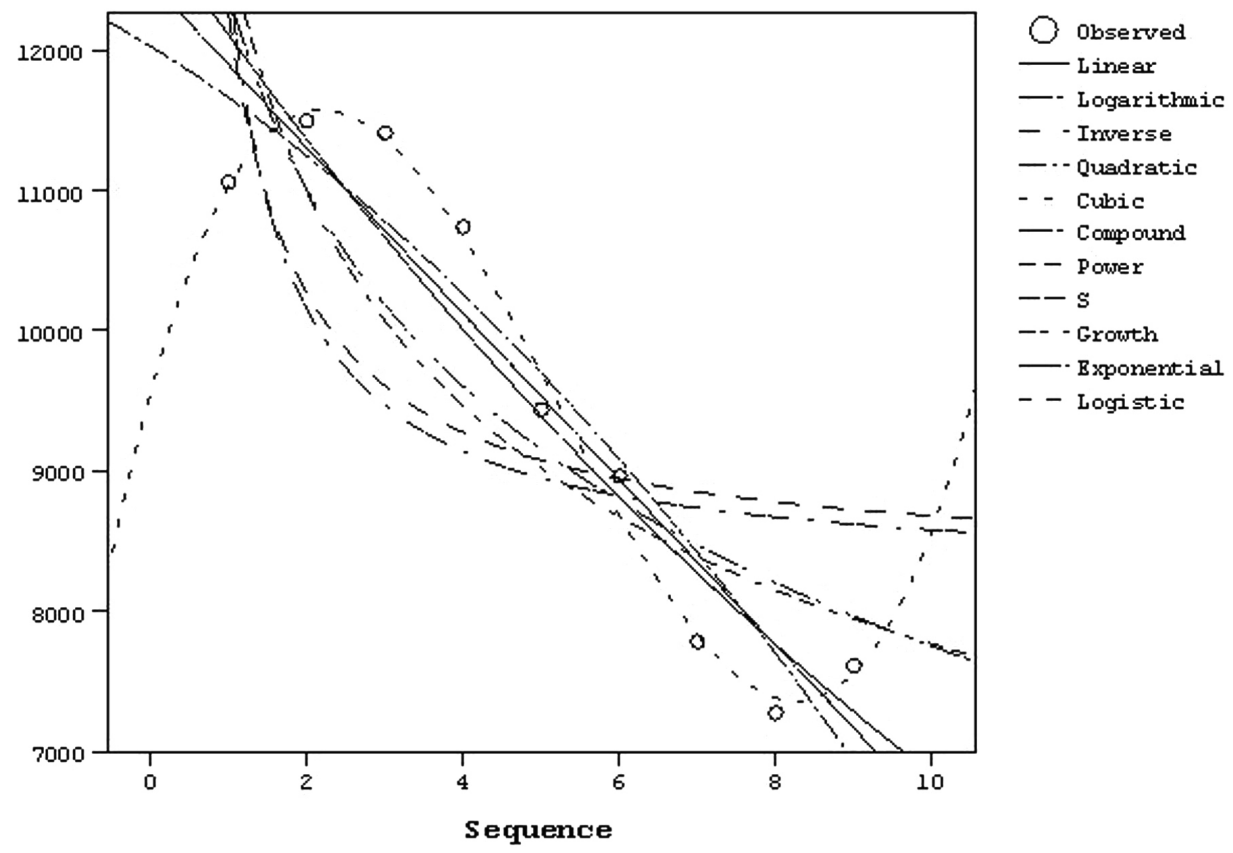

- The time series data that cover external migrations in the Republic of Macedonia from 2003 to 2011 can be also approximated most accurately by the cubic trend model (2), since it has the highest value of the coefficient of determination (0.739) among all other presented theoretical models; Equation (2) can be utilized for predicting the values of external migrations in the forthcoming years; The cubic trend approximation can be seen on Figure 7, based on the model summary depicted by Table 6 .

$$
\begin{aligned}
& \hat{y}_{i}=-1430.151+3138.182 \cdot x-677.310 \cdot x^{2}+44.864 \cdot x^{3} \\
& i=1,2, \ldots, n
\end{aligned}
$$


Figure 7. Choosing the best fit approximation trend for the external migrations in the Republic of Macedonia (2003 - 2011)

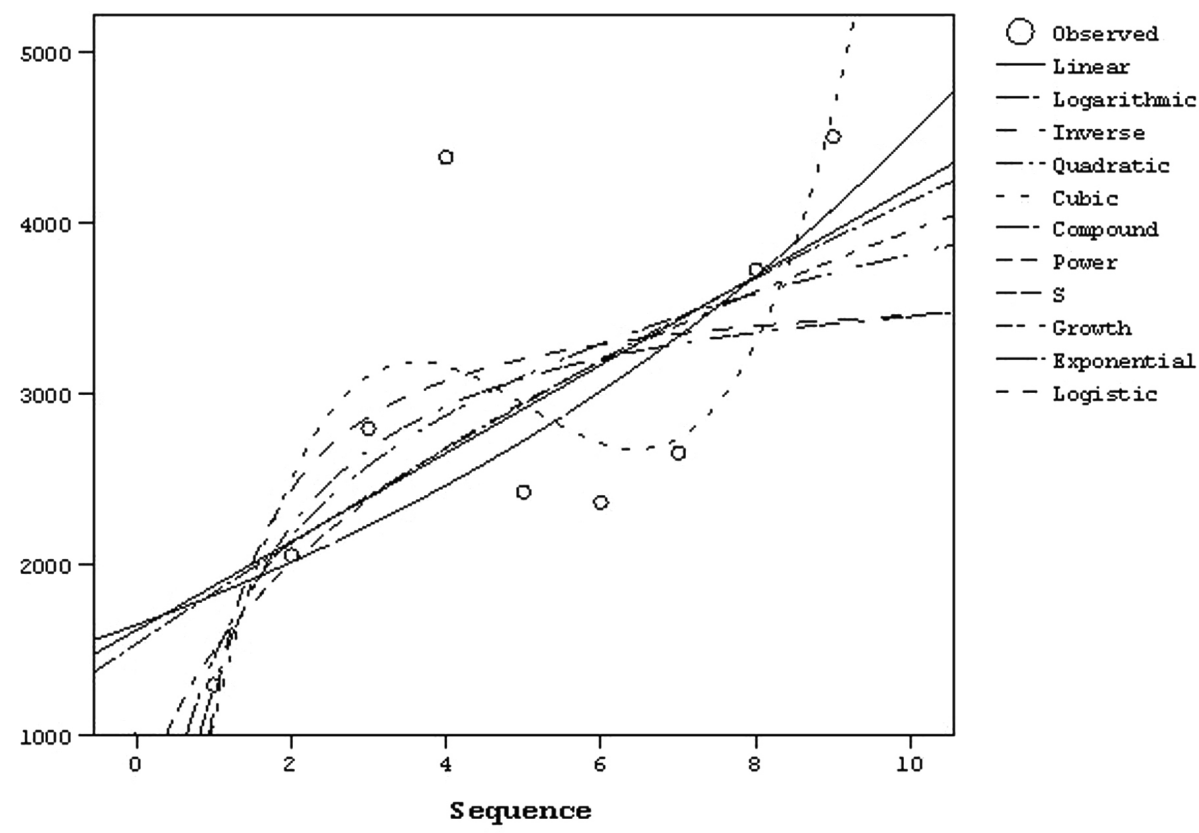

Taking into account the interaction between population migrations and economic factors, a plethora of regression models can be developed, bearing in mind that immigration and emigration rates are both dependent variables, whilst independent variables are the indicators of the regional development of the Republic of Macedonia, taken by different statistical regions, including the following ones: the Unemployment Rate, GDP per capita, Average Net Wage per employee, as well as Gross Fixed Capital Formation (Table 7). 
Table 7. Regional development indicators for the Republic of Macedonia, by statistical regions

\begin{tabular}{|c|c|c|c|c|}
\hline Statistical regions & $\begin{array}{l}\text { Unemployment } \\
\text { rate } \\
{[\%](2011)}\end{array}$ & $\begin{array}{l}\text { GDP per } \\
\text { capita } \\
\text { [US\$] } \\
(2010)\end{array}$ & $\begin{array}{l}\text { Net } \\
\text { wage per } \\
\text { employee } \\
\text { [MKD] } \\
(2011)\end{array}$ & $\begin{array}{l}\text { Gross fixed } \\
\text { capital } \\
\text { formation } \\
\text { [MKD] } \\
\text { in millions } \\
(2010)\end{array}$ \\
\hline Pelagonia region & 31.4 & 225,437 & 19,312 & 6,295 \\
\hline Vardar region & 36.4 & 206,667 & 16,125 & 5,066 \\
\hline North-east region & 59.6 & 108,664 & 17,009 & 2,150 \\
\hline South-west region & 42.8 & 155,572 & 18,499 & 3,889 \\
\hline Skopje region & 30.7 & 314,809 & 24,693 & 45,323 \\
\hline South-east region & 9.3 & 219,714 & 16,169 & 5,773 \\
\hline Polog region & 31.8 & 98,848 & 19,784 & 6,518 \\
\hline East region & 16.4 & 206,770 & 15,131 & 7,953 \\
\hline Rep. of Macedonia & Average: 32.3 & $\begin{array}{l}\text { Average: } \\
192,060\end{array}$ & $\begin{array}{l}\text { Average: } \\
18,340\end{array}$ & $\begin{array}{l}\text { Total: } \\
82,967\end{array}$ \\
\hline
\end{tabular}

Sources: Регионите во Република Македонија, 2012 / Regions of the Republic of Macedonia, 2012 (2012), Скопје / Skopје, Државен завод за статистика на Република Македонија / State Statistical Office of the Republic of Macedonia.

\section{Linear regression model \#1: Using the Immigration Rate as a dependent variable}

Based on partial correlation analysis, it is evident that there is a strong positive correlation between the Gross Fixed Capital Formation and:

- Average Net Wage per employee (0.829);

- GDP per capita (0.744).

There is a moderate negative correlation between the Immigration Rate and:

- Gross Fixed Capital Formation (-0.345);

- Average Net Wage per employee (-0.478);

- Unemployment Rate (-0.336). 
It can be also noted that there is a very weak correlation between GDP per capita and the Immigration Rate values.

The equation of the regression model that encompasses the previously defined economic factors and statistical regions can be specified using the values of the regression coefficients (Table 8). It can then be used for estimating the value of the Immigration Rate for various values of the independent variables (the Unemployment Rate, Gross Fixed Capital Formation, the Average Net Wage per employee, and GDP per capita).

Table 8. Regression coefficients for the linear regression model \#1

\begin{tabular}{|c|c|c|c|c|c|c|}
\hline \multicolumn{2}{|c|}{ Model* } & \multicolumn{2}{|c|}{$\begin{array}{l}\text { Unstandardized } \\
\text { Coefficients }\end{array}$} & \multirow{3}{*}{$\begin{array}{l}\text { Standardized } \\
\text { Coefficients } \\
\text { Beta }\end{array}$} & \multirow{3}{*}{$\begin{array}{c}\mathbf{t} \\
.582 \\
\end{array}$} & \multirow{3}{*}{$\begin{array}{l}\text { Sig. } \\
.601 \\
\end{array}$} \\
\hline & & \multirow{2}{*}{$\begin{array}{l}B \\
2.206\end{array}$} & \multirow{2}{*}{$\begin{array}{l}\text { Std. Error } \\
3.789\end{array}$} & & & \\
\hline 1 & (Constant) & & & & & \\
\hline & $\begin{array}{l}\text { Unemployment } \\
\text { rate }\end{array}$ & .001 & .023 & .023 & .052 & .962 \\
\hline & GDP per capita & $1.241 \mathrm{E}-005$ & .000 & 1.101 & 1.627 & .202 \\
\hline & $\begin{array}{l}\text { Net wage per } \\
\text { employee }\end{array}$ & 6.323E-006 & .000 & .024 & .033 & .976 \\
\hline & $\begin{array}{l}\text { Gross fixed } \\
\text { capital formation }\end{array}$ & $-6.553 \mathrm{E}-005$ & .000 & -1.181 & -1.203 & .315 \\
\hline
\end{tabular}

* Dependent Variable: Immigration rate

The value of the multiple linear correlation coefficient, $R=0.794$, shows that the correlation between the Unemployment rate, Gross Fixed Capital Formation, the Average Net Wage per employee, GDP per capita, and the Immigration Rate is statistically significant.

The value of the coefficient of multiple linear determination, $\mathrm{R}^{2}=0.630$, shows that $63 \%$ of the Immigration Rate variability emerges as a result of the variability of the Unemployment Rate, Gross Fixed Capital Formation, the Average Net Wage per employee, and GDP per capita, whilst $37 \%$ of the Immigration Rate variability is due to other factors and random variations that are not taken into account by the regression model.

For $v_{1}=5-1=4$ and $v_{2}=9-5=4$ degrees of freedom, the theoretical value of the F statistics, $F_{t}=6.39$.

Since the empirical value of the F statistics (1.279) is less than the corresponding theoretical value (6.39), and taking into account an error margin of $5 \%$, it can be concluded that the Unemployment Rate, the Gross Fixed Ca- 
pital Formation, the Average Net Wage per employee, and GDP per capita do not differ in their impact on the Immigration Rate.

\section{Linear regression model \#2: Using the Emigration Rate as a dependent variable}

The values of the partial correlation coefficients imply that there is a strong positive correlation between Gross Fixed Capital Formation and:

- Average Net Wage per employee (0.829);

- GDP per capita (0.744).

On the other hand, there is a moderate negative correlation between the Emigration Rate and:

- Gross Fixed Capital Formation (-0.495);

- Average Net Wage per employee (-0.474).

It can be also observed that there is a weak correlation among GDP per capita, the Unemployment Rate, and the Emigration Rate.

Again, the equation of the regression model that encompasses the previously defined economic factors and statistical regions can be specified using the values of the regression coefficients (Table 9). It then can be used for estimating the value of the Emigration Rate for various values of the independent variables (the Unemployment Rate, Gross Fixed Capital Formation, the Average Net Wage per employee, and GDP per capita).

Table 9. Regression coefficients for the linear regression model \#2

\begin{tabular}{|c|c|c|c|c|c|c|}
\hline \multirow{2}{*}{\multicolumn{2}{|c|}{ Model* $^{*}$}} & \multicolumn{2}{|c|}{$\begin{array}{l}\text { Unstandardized } \\
\text { Coefficients }\end{array}$} & \multirow{3}{*}{$\begin{array}{l}\text { Standardized } \\
\text { Coefficients } \\
\text { Beta } \\
\end{array}$} & \multirow{3}{*}{$\begin{array}{l}\mathbf{t} \\
.343\end{array}$} & \multirow{3}{*}{$\begin{array}{l}\text { Sig. } \\
.754\end{array}$} \\
\hline & & \multirow{2}{*}{$\begin{array}{l}B \\
4.626\end{array}$} & \multirow{2}{*}{$\begin{array}{l}\text { Std. Error } \\
13.491\end{array}$} & & & \\
\hline 1 & (Constant) & & & & & \\
\hline & $\begin{array}{l}\text { Unemployment } \\
\text { rate }\end{array}$ & .021 & .082 & .159 & .258 & .813 \\
\hline & GDP per capita & $1.014 \mathrm{E}-005$ & .000 & .349 & .373 & .734 \\
\hline & $\begin{array}{l}\text { Net wage per } \\
\text { employee }\end{array}$ & -8.359 E-005 & .001 & -.125 & -.121 & .911 \\
\hline & $\begin{array}{l}\text { Gross fixed capital } \\
\text { formation }\end{array}$ & -8.972E-005 & .000 & -.628 & -.463 & .675 \\
\hline
\end{tabular}

* Dependent Variable: Emigration Rate 
The value of the multiple linear correlation coefficient, $\mathrm{R}=0.541$, shows that the correlation between the Emigration Rate and the Unemployment Rate, Gross Fixed Capital Formation, the Average Net Wage per employee, and GDP per capita is significant.

The value of the multiple linear determination coefficient, $R^{2}=0.293$, implies that $29.3 \%$ of the Emigration Rate's variations exist as a result of the variations in the Unemployment Rate, Gross Fixed Capital Formation, the Average Net Wage per employee, and GDP per capita, whilst $70.7 \%$ of the Emigration Rate's variations are due to other factors and uncertainties that have not been taken into account within the regression model.

For $v_{1}=5-1=4$ and $v_{2}=9-5=4$ degrees of freedom, the theoretical value of the F statistics, $F_{t}=6.39$.

Since the empirical value of the F statistics (0.311) is less than the corresponding theoretical value (6.39), and taking into account an error margin of $5 \%$, it can be concluded that the Unemployment Rate, Gross Fixed Capital Formation, the Average Net Wage per employee, and GDP per capita do not differ in their impact on the Emigration Rate. Even though their impact is statistically significant, it is not crucial or decisive for the values of the Emigration Rate. To be more precise, there are other factors that are not included in the model, being more significant in determination of the variability of the Emigration Rate.

\section{STATISTICAL INFERENCES ABOUT THE POPULATION MIGRATION}

Based on the previously determined indicators about the population migration in the Republic of Macedonia, given by statistical regions and in the observed time period, the following statistical hypotheses can be defined:

\section{Hypothesis \#1:}

- There were no significant differences in the values of the Immigration and Emigration Rates in 2000, among different statistical regions; and,

- There were no significant differences in the values of the Immigration and Emigration Rates in 2000, within each statistical region.

The usage of the parametric ANOVA statistical test (Groebner et al., 2005: 429-439) results in the following conclusions:

- There is a statistically significant difference in the values of the Immigration and Emigration Rates in 2000 between the different statistical regions, since 
the computed value of the F statistics (20.390) is much higher than the theoretical one, F crit (3.787); Alternatively, one can accept the null hypothesis, since the $P$-value of 0.000 is smaller than the error margin of 5\% (Table 10);

- There is no statistically significant difference in the values of the Immigration and Emigration Rates in 2000, within each statistical region, since the computed value of the F statistics (0.164) is much lower than the theoretical one, F crit (5.591); Alternatively, one can reject the null hypothesis since the $P$-value of 0.697 is higher than the error margin of 5\% (Table 10).

Table 10. Two-factor ANOVA without replication: Immigration and Emigration Rates (2000) / Statistical regions

\begin{tabular}{lllllll}
\hline $\begin{array}{l}\text { Source of } \\
\text { Variation }\end{array}$ & SS & df & MS & F & P-value & F crit \\
\hline Rows & 50.582 & 7 & 7.226 & 20.390 & 0.000 & 3.787 \\
\hline Columns & 0.058 & 1 & 0.058 & 0.1643 & 0.697 & 5.591 \\
\hline Error & 2.481 & 7 & 0.354 & & & \\
\hline Total & 53.121 & 15 & & & & \\
\hline
\end{tabular}

\section{Hypothesis \#2:}

- There are no significant differences in the values of the Immigration and Emigration rates in 2011, between different statistical regions; and,

- There are no significant differences in the values of the Immigration and Emigration Rates in 2011, within each statistical region.

The usage of the parametric ANOVA statistical test results in the following conclusions:

- There was no statistically significant difference in the values of the Immigration and Emigration Rates in 2011, between different statistical regions, since the computed value of the F statistics (3.220) is lower than the theoretical one, F crit (3.787); Alternatively, one can reject the null hypothesis since the $P$-value of 0.073 is higher than the error margin of 5\% (Table 11);

- There was no statistically significant difference in the values of the Immigration and Emigration Rates in 2011, within each statistical region, since the 
computed value of the F statistics (1.869) is lower than the theoretical one, $F$ crit (5.591); Alternatively, one can reject the null hypothesis since the $P$-value of 0.214 is higher than the error margin of $5 \%$ (Table 11).

Table 11. Two-factor ANOVA without replication: Immigration and Emigration Rates (2011) / Statistical regions

\begin{tabular}{lllllll}
\hline $\begin{array}{l}\text { Source of } \\
\text { Variation }\end{array}$ & SS & df & MS & F & P-value & F crit \\
\hline Rows & 25.422 & 7 & 3.632 & 3.220 & 0.073 & 3.787 \\
\hline Columns & 2.109 & 1 & 2.109 & 1.869 & 0.214 & 5.591 \\
\hline Error & 7.896 & 7 & 1.128 & & & \\
\hline Total & 35.427 & 15 & & & & \\
\hline
\end{tabular}

\section{Hypothesis \#3:}

- There are no statistically significant differences between the values of the Immigration rate for 2000 and 2011 between the different statistical regions; and,

- There are no statistically significant differences between the values of the Immigration rate for 2000 and 2011, within each statistical region.

By employing the ANOVA parametric test, the following statistical conclusions can be drawn:

- There is no statistically significant difference between the values of the Immigration rate for 2000 and 2011 between the different statistical regions, since the computed value of the F statistics (0.748) is lower than the theoretical one, $F$ crit (3.787); Alternatively, one can reject the null hypothesis since the $P$-value of 0.644 is higher than the error margin of 5\% (Table 12);

- There is no statistically significant difference between the values of the Immigration Rate for 2000 and 2011 within each statistical region, since the computed value of the F statistics (3.818) is lower than the theoretical one, $F$ crit (5.591); Alternatively, one can reject the null hypothesis since the $P$-value of 0.092 is higher than the error margin of $5 \%$ (Table 12). 
Table 12. Two-factor ANOVA without replication: Immigration Rate (2000 and 2011) / Statistical regions

\begin{tabular}{lllllll}
\hline $\begin{array}{l}\text { Source of } \\
\text { Variation }\end{array}$ & SS & df & MS & F & P-value & F crit \\
\hline Rows & 14.179 & 7 & 2.026 & 0.748 & 0.644 & 3.787 \\
\hline Columns & 10.338 & 1 & 10.338 & 3.818 & 0.092 & 5.591 \\
\hline Error & 18.954 & 7 & 2.709 & & & \\
\hline Total & 43.472 & 15 & & & & \\
\hline
\end{tabular}

\section{Hypothesis \#4:}

- There are no statistically significant differences between the values of the Emigration Rate for 2000 and 2011 between the different statistical regions; and,

- There are no statistically significant differences between the values of the Emigration Rate for 2000 and 2011 within each statistical region.

By employing the ANOVA parametric test, the following statistical conclusions can be drawn:

- There is no statistically significant difference between the values of the Emigration Rate for 2000 and 2011 between different statistical regions, since the computed value of the F statistics $(0.585)$ is lower than the theoretical one, F crit (3.787); Alternatively, one can reject the null hypothesis since the $P$-value of 0.752 is higher than the error margin of 5\% (Table 13);

- There is no statistically significant difference between the values of the Emigration Rate for 2000 and 2011 within each statistical region, since the computed value of the F statistics (0.837) is lower than the theoretical one, F crit (5.591); Alternatively, one can reject the null hypothesis since the $P$-value of 0.391 is higher than the error margin of 5\% (Table 13 ). 
Table 13. Two-factor ANOVA without replication: Emigration Rate (2000 and 2011) / Statistical regions

\begin{tabular}{lllllll}
\hline $\begin{array}{l}\text { Source of } \\
\text { Variation }\end{array}$ & SS & df & MS & F & P-value & F crit \\
\hline Rows & 19.660 & 7 & 2.808 & 0.585 & 0.752 & 3.787 \\
\hline Columns & 4.018 & 1 & 4.018 & 0.837 & 0.391 & 5.591 \\
\hline Error & 33.587 & 7 & 4.798 & & & \\
\hline Total & 57.264 & 15 & & & & \\
\hline
\end{tabular}

\section{CONCLUSIONS}

The population migration flows in the Republic of Macedonia, being observed and analyzed by statistical regions in the specified period from 2000 to 2011, are continuous and varying processes, which have a significant impact on the further demographic image, structure and development of the country. This assumption can be confirmed by the declining immigration rate, i.e. the decrease of the total number of immigrants in the country. The beginning of the $21^{\text {st }}$ century in the Republic of Macedonia is also characterized by an evident decrease in the total number of emigrants within the country, being evident in all statistical regions. Quite the opposite, a significant increase in the total number of emigrant inhabitants towards third countries has been recorded for the same time period, i.e. the emigration rate is continuously rising. As a direct consequence of such trends, the migration balance rate transforms from a positive to a negative one, meaning that more inhabitants have emigrated than have immigrated from/into the country in this period of time.

The analysis of the internal migrations time series for the observed time period shows that there is an obvious continuous decrease, whilst the one corresponding to the external migrations generally exhibits an increasing tendency. Both time series trends can be approximated in a most appropriate way by a cubic model, as a basis for predicting future expected values for both the internal and external migration flows.

Many socio-economic phenomena are thought to be causes for such immigration and emigration rates in the country, including the following ones: Gross Fixed Capital Formation, the Average Net Wage per employee, GDP per capita, as well as the Unemployment Rate. The statistical analysis 
confirms that all of these are negatively correlated to the Immigration and Emigration Rates. In addition, all of these have a more significant impact on the Immigration Rate than on the Emigration Rate.

Our statistical analyses also show that there are no statistically significant differences in the values of both the Immigration Rates and the Emigration Rates for all statistical regions within the country, for the compared time periods. An identical conclusion can be drawn for the structure of the immigrants regarding their gender, marital status, age, ethnicity and the reasons for immigration.

All these findings confirm and point to the necessity of continuous acquisition, arranging, analyzing, and assessment of relevant data about migration flows from/to and within the country, which already faces abundant problems and challenges regarding the population economic and social discrepancies, and undesirable demographic trends in the last decade. A further persistent study of the volume, dynamics, and types of migrations, leading towards creating annual migration profiles of the country, will have immense significance in planning demographic and socio-economic progress on a national level, which can facilitate the consistent implementation of the National Strategy for sustainable demographic development of the Republic of Macedonia and other vital strategic documents. However, the accomplishment of these goals relies on several key premises, including: (1) design, implementation, and maintenance of a unique national statistical database about migrants and migration flows, (2) better coordination and more intensive collaboration between authorities and all relevant governmental institutions, bodies, organizations, groups and associations, as well as (3) wider and more substantial support to all research institutions, academia and individuals treating the issue of migrations in the Republic of Macedonia.

\section{REFERENCES}

Abdulai, J., Durmishi, I. and Kadrius, B. (2012). The Social Changes and the Migration from the Gostivar Region to the Western Countries, International Scientific Conference "Migration and Labour Market", Krushevo, October 19-20, 2012.

Allen, P. and Bennett, K. (2012). SPSS Statistics: A Practical Guide, Version 20. $2^{\text {nd }}$ ed. South Melbourne: Cengage Learning.

Avirović, I. (2012). Macedonian Post-Socialist Migration, Conference "(In-)Equality Political, Economic, Social, Gender and Spatial Aspects", Vienna, December 6-8, 2012.

Bejzaroski, L. (2012). Migration and the Labour Market, International Scientific Conference "Migration and Labour Market", Krushevo, October 19-20, 2012. 
Bornarova, S. and Janeska, V. (2012). Social Impact of Emigration and Rural-Urban Migration in Central and Eastern Europe: Final Country Report - The Former Yugoslav Republic of Macedonia. European Commission, DG Employment, Social Affairs and Inclusion GVG.

Бубевски, Д. (2001). Некои аспекти на социо-економската структура и проблеми на населението во Република Македонија [Some Aspects of the Socio-Economic Structure and Problems of the Population in the Republic of Macedonia], in: J. Jakimovski et al. (eds). Социо-економска структура и проблеми на населението во Република Македонија. Скопје: Институт за социолошки и подитичко-правни истражувања, 21-23.

Cacanoska, R. and Slaninka-Dineva, M. (2012). Migration and Demographic Changes, International Scientific Conference "Migration and Labour Market", Krushevo, October 19-20, 2012.

Chudoska-Blazevska, I., Malici, N. and Zununi, Z. (2012). International Economic Immigration as a Global Phenomenon, International Scientific Conference "Migration and Labour Market", Krushevo, October 19-20, 2012.

Gjurovski, S. (2012). Migration of Population in Mariovo Region, International Scientific Conference "Migration and Labour Market", Krushevo, October 19-20, 2012.

Groebner, D. F., Shannon, W. P., Fry, C. P. and Smith, D. K. (2005). Business Statistics: A Decision-making Approach. Upper Saddle River: Pearson Education International.

Ivanovska, M. and Jovcheska, S. (2012). The Educated Unemployment and the Emigration - Review of the Situation in Macedonia, International Scientific Conference "Migration and Labour Market", Krushevo, October 19-20, 2012.

Јакимовски, J. (2007). Демографски движења и структура на населението во регионот на Скопје [Demographic Trends and Population Structure in the Region of Skopje], in: Актуелните демографски движеньа во Република Македонија во светлоста на резултатите на пописот на населенето во 2002 година: прилози од научниот собир одржан на 2 и 3 јуни 2005 година во Cкопје / Actual Demographic Trends in the Republic of Macedonia in the light of the Results of the Population Census in 2002: proceedings of a scientific meeting held on 2nd and 3rd June 2005 in Skopje. Скопје: Македонска академија на науките и уметностите, 127-141.

Janeska, V. (2013). Labor Market and Labor Migration in the Republic of Macedonia, $6^{\text {th }}$ IZA/ASE Workshop on EU Enlargement and the Labor Markets, Bucharest, 25-26 November 2013.

Јанеска, В. and Ивановска, А. (2007). Преселничките движења во Република Македонија во периодот на транзиција [Migratory Movements in the Republic of Macedonia in the Period of Transition], in: Актуелните демографски движень во Република Македонија во светлоста на резултатите на пописот на населенето во 2002 година: прилози од научниот собир одржан на 2 и 3 јуни 2005 година во Скопје I Actual Demographic Trends in the Republic of Macedonia in the light of the Results of the Population Census in 2002: proceedings of a scientific meeting held on 2 nd and 3rd June 2005 in Skopje. Скопје: Македонска академија на науките и уметностите, 211-234.

Joveski, Z. B. (2012). Forms of Illegal and Forced Migration in the Republic of Macedonia, Security Dialogues, 3 (2): 59-74.

Kirkpatrick, L. A. and Feeney, B. C. (2012). A Simple Guide to IBM SPSS ${ }^{\circledast}$ Statistics: for Version 20.0. $12^{\text {th }}$ ed. Belmont CA: Wadsworth Cengage Learning. 
Кљусев, Н. (2007). Актуелните демографски движења во Република Македонија [Actual Demographic Movements in the Republic of Macedonia], in: Aкmyeлните демографски движена во Република Македонија во светлоста на резултатите на пописот на населенето во 2002 година: прилози од научниот собир одржан на 2 и 3 јуни 2005 година во Cкоnje / Actual Demographic Trends in the Republic of Macedonia in the light of the Results of the Population Census in 2002: proceedings of a scientific meeting held on 2nd and 3rd June 2005 in Skopje. Скопје: Македонска академија на науките и уметностите, 15-27.

Klopchevska, V. (2012). The Socio-Economic Position and the Migration of the Roma Population in the Municipality of Debar, International Scientific Conference "Migration and Labour Market", Krushevo, October 19-20, 2012.

Kranzler, J. H. (2007). Statistics for the Terrified. $4^{\text {th }}$ ed. Upper Saddle River: Prentice Hall.

Митковска, И. (2014). Се раѓа третата генерација Македонци надвор од татковината: од Македонија ќе наследат само пасош и право да гласаат [A Third Generation of Macedonians is being born outside the fatherland: from Macedonia they will inherit only a passport and a right to vote], Слободен печат, Скопје, 05. 05. 2014.

Nikolovski, M., Žibak, M. and Nikolovska, F. (2012). Illegal Migration and Illegal Competition on the Labour Market, International Scientific Conference "Migration and Labour Market", Krushevo, October 19-20, 2012.

НТЕС - Номенклатура на територијални единици за статистика на Република Македонија [Nomenclature of Territorial Units for Statistics of the Republic of Macedonia], (2005). Скопје: Државен завод за статистика на Република Македонија.

НТЕС - Номенклатурата на територијални единици за статистика на Република Македонија [Nomenclature of Territorial Units for Statistics of the Republic of Macedonia], Службен весник на PM, no. 158/2007.

Popovski, V. and Tosheva, E. (2012). Migratory Movements in the Republic of Macedonia and Labour Market: Implications for the Regional Economic Development, International Scientific Conference "Migration and Labour Market", Krushevo, October 19-20, 2012.

Регионите во Република Македонија, 2012 / Regions of the Republic of Macedonia, 2012 (2012). Скопје / Skopje: Државен завод за статистика на Република Македонија / State Statistical Office of the Republic of Macedonia, http://www.stat.gov.mk/ Publikacii/Regioni2012.pdf (7 May 2014).

Resolution on Migration policy of Republic of Macedonia: 2009-2014 (2008). Skopje: Government of the Republic of Macedonia, http://www.marri-rc.org/upload/ Documents/MKD\%20M\%20R\%202009-2014.pdf (7 May 2014).

Сотироски, К. (2004). Статистика [Statistics]. Прилеп: Економски факултет.

Стратегија за демографски развој на Република Македонија: 2008 - 2015 [Strategy for a Demographic Development of the Republic of Macedonia: 2008 - 2015]. Ckonje: Министерството за труд и социјална политика.

Талевски, J. Д. (2007). Значајни карактеристики на миграциониот биланс [Important Characteristics of Migration Balance], in: Актуелните демографски движеньв во Република Македонија во светлоста на резултатите на пописот на населенето во 2002 година: прилози од научниот собир одржан на 2 и 3 јуни 2005 година во Скопје I Actual Demographic Trends in the Republic of Macedonia in the light of the Results of the Population Census in 2002: proceedings of a scientific meeting held on 2nd and 3rd June 2005 in Skopje. Скопје: Македонска академија на науките и уметностите, 235-249. 
Trajkova, K. and Andonov, M. (2012). Aspects in the Internal Migrations in the Republic of Macedonia with a Special Emphasis on Their Influence over the Demographic and the Economic Development, International Scientific Conference "Migration and Labour Market", Krushevo, October 19-20, 2012.

Vchkov, Lj. (2012). Migration and the Standard of Life of the Population, International Scientific Conference "Migration and Labour Market", Krushevo, October 19-20, 2012.

\section{SOURCES}

Mиграции, 2007 / Migrations, 2007 (2008). Скопје: Државен завод за статистика на Република Македонија / Skopje: State statistical office of the Republic of Macedonia.

Миграции, 2008 / Migrations, 2008 (2009). Скопје: Државен завод за статистика на Република Македонија / Skopje: State statistical office of the Republic of Macedonia.

Мuграциuи, 2009 / Migrations, 2009 (2010). Скопје: Државен завод за статистика на Република Македонија / Skopje: State statistical office of the Republic of Macedonia.

Muгpauиu, 2010 / Migrations, 2010 (2011). Скопје: Државен завод за статистика на Република Македонија / Skopje: State statistical office of the Republic of Macedonia.

Мигращии, 2011 / Migrations, 2011 (2012). Скопје: Државен завод за статистика на Република Македонија / Skopje: State statistical office of the Republic of Macedonia.

Statistical Yearbook of the Republic of Macedonia: 2000 (2001). Skopje: State Statistical Office of Republic of Macedonia.

Statistical Yearbook of the Republic of Macedonia: 2001 (2002). Skopje: State Statistical Office of Republic of Macedonia.

Statistical Yearbook of the Republic of Macedonia: 2011 (2012). Skopje: State Statistical Office of Republic of Macedonia. 


\section{Statistički pokazatelji migracija u Republici Makedoniji na početku 21. stoljeća}

\section{Kosta Sotiroski, Ilija Hristoski}

\section{SAŽETAK}

Republika Makedonija uvijek se smatrala vrlo izraženim migracijskim područjem koje obilježava veliko unutarnje kretanje stanovništva kao i stalni emigracijski procesi prema drugim zemljama. U središtu ovoga rada su ispitivanje i analiza obima, dinamike, trendova, demografskih karakteristika i promjena modaliteta migracijskih tokova u zemlji tijekom prvog desetljeća 21. stoljeća te njihovo međudjelovanje i učinci na socioekonomske čimbenike. Imajući na umu različitosti migracijskih tokova unutar zemlje, očekivani ishodi usmjereni su prema otkrivanju relevantnih informacija o njihovim promjenama, kretanjima i uzajamnom djelovanju utemeljenom na indikatorima dobivenim uporabom relevantne statističke metrike i podacima koji prikazuju razvoj statističkih regija u određenom razdoblju.

KLJUČNE RIJEČI: migracijski saldo, imigracija, emigracija, indikatori regionalnog razvoja, statističko zaključivanje, Republika Makedonija 